\title{
An ounce of time, a pound of responsibilities and a ton of weight to lose: An autoethnographic journey of barriers, message adherence and the weight-loss process
}

Public Relations Inquiry 2(I) 95-116

(C) The Author(s) 2013

Reprints and permission: sagepub.co.uk/journalsPermissions.nav DOI: $10.1177 / 2046 \mid 47 \times 12460949$ pri.sagepub.com @SAGE

\author{
Christal R.S. Johnson \\ Howard University, USA
}

\section{Katherine L. Eaves}

University of Oklahoma, USA

\begin{abstract}
This article uses an autoethnographic approach to determine how the intersectionality of identities affects message perceptions about weight loss from the lens of two doctoral students. This autoethnography links our personal experiences with the societal and cultural phenomena of obesity and weight loss, and the rhetoric of messages. We know there is a gap in public relations literature about autoethnography, health communication and intersectionality, and we hope to fill it. We also know health communicators seek more effective ways to reach an increasingly diverse audience; we hope to shed light on the issue. We know that many women want to lose weight and hope our narratives will resonate with them. Finally, we recognize autoethnographic skeptics exist in academia, and we hope our article provides insight into and understanding of the usefulness of autoethnographies in the field of public relations.
\end{abstract}

\section{Keywords}

Autoethnography, identity, messages, public relations, weight loss

\section{Corresponding author:}

Christal R. S. Johnson, Howard University, Journalism Department, 525 Bryant St. NW, Washington, DC 20059, USA.

Email: christal.johnson@howard.edu 
An increasingly diverse society calls for alternative methodologies in public relations research that account for the multiple identities that exist among organizations' publics. Autoethnography is one such methodology that helps explain the lived experiences of diverse audiences and provides rich data by which public relations scholars and practitioners can develop a more thorough understanding of how publics process information (L'Etang et al., 2010).

There is a compelling need to understand how audiences process health information as the public's desire for health news increases (Avery, 2010). The more effective the health messages, the more active and involved publics become in their health decisions. An effective message includes one that speaks to an audience member's health in reference to her gender, occupation, social and economic status, and other factors that may affect how she makes decisions about her health. Thus, public relations professionals must address the audience's intersectionality of identities when examining how recognition, involvement and constraints play a role in processing health information. According to Vardeman-Winter and Tindall, the continuous exclusion of discourse on the intersectionality of identities in the development of public relations theory and practice 'hinders how public relations practitioners communicate effectively with the varied publics that enact and engage organizations' (2010: 3). Intersectionality refers to the 'multiple, interdependent identities that simultaneously impact groups' (VardemanWinter et al., 2010: 4-5).

Despite the importance of autoethnographies, health messages and intersectionality, little exists in public relations literature about these topics (Avery, 2010; L'Etang et al., 2010; Vardeman-Winter and Tindall, 2010). This article will contribute to the body of literature by introducing autoethnography as a means of offering rich, thick description in understanding how publics interpret health messages. The article will also examine the intersectionality of identities, which contributes to more effective segmentation of publics when it comes to health campaigns.

We know there is a gap in public relations literature about autoethnography, health messages and intersectionality, and we hope to fill it. We also know health communicators seek ways to better communicate with an increasingly diverse audience; we hope to shed light on the issue. We know many women want to lose weight and hope our narratives will resonate with them. Finally, we recognize autoethnographic skeptics exist in academia, and we hope our article provides insight into and understanding of the usefulness of autoethnographies in the field of public relations.

Traditional qualitative methods such as interviews and focus groups lack the ability to fully capture the complexities of lived experiences. While interview and focus group respondents may be able to provide rich, detailed data and poignant narratives, the process by which the data is collected sometimes restricts the ability of a researcher to capture every detail and unpack the complicated and intertwined identities of each respondent. Autoethnographies, however, give researchers the advantage of living in the study because the researcher becomes the researched. In other words, it allows the researcher the ability to fully grasp the multiple identities that impact message interpretation because those identities are the researcher's own (Wall, 2006).

This article will first offer a brief overview of health communication, audiencecentered research, intersectionality, obesity and autoethnographic research. Next, 
explanation of the authors' autoethnographic journey is presented, followed by the autoethnographies. Finally, the article discusses how public relations scholarship can benefit from the authors' autoethnographies and offer suggestions for future research.

\section{Literature review}

The first step in our autoethnographic journey was selecting a topic. My co-author Katie and I agreed that obesity, health messages, audience-centered research, and identities are relevant subjects worthy to be explored in public relations as exemplified in extant literature.

\section{Obesity}

Globally, 300 million women and 200 million men are obese (World Health Organization, 2011). The rise in obesity (Body Mass Index $\geq 30$ ) has contributed to an increase in healthcare costs as well as escalating rates of heart disease, diabetes, cancer, stroke, respiratory problems, osteoarthritis, gynecological problems and death (Centers for Disease Control, 2009). Obesity is such a growing concern such that US First Lady Michele Obama has implemented the 'Let's Move!' campaign in the USA to help combat the disease. Although this health epidemic persists in America, there is a dearth of public relations scholarship about obesity and other health-related messages that encourage publics to become more active and involved in information seeking and improving their healthcare.

\section{Health communication}

Approximately $65 \%$ of adults closely follow health news (Pew Research Center, 2010). Furthermore, two-thirds of adults with internet access use web-based search engines to find health-related information (iCrossing, 2008). Thus, audiences have a need for health information, and this need is a reason for practitioners to examine how its key publics interpret health communication. However, merely providing information is not enough. Disseminating accurate information to target audiences plays a significant role in helping publics improve their health decisions (Avery, 2010). For example, in the case of HIV/AIDs, research has shown that early HIV/AIDs literature and prevention programs were designed for White males, which led the African American community to believe that HIV/AIDS was a 'White gay male' disease (Wang and Arpan, 2008). Sadly, the highest prevalence of HIV/AIDs-related deaths from 1990-2008 has been among African Americans (Centers for Disease Control, 2012). Health communication research, therefore, is needed in the public relations field to ensure accurate delivery of information to decrease health disparities that ultimately may help save lives.

Little is known, however, about public relations activities in the health arena, and more research is needed to help public health bodies at the federal, state and local levels communicate more effectively with target audiences (Wise, 2001). Audience-centered research needs to be implemented to bring this mandate into fruition. 


\section{Audience-Centered Research}

Campaign planners often roll out health campaigns without exploring what messages resonate with publics (Vardeman-Winter and Tindall, 2010). This results in failed attempts to increase the salience of, and attention to, health messages in the campaigns (Avery, 2010; Pratt, 2007). For example, the US Government's 'Just Say No' campaign in the 1980s, aimed at decreasing drug use and increasing self-esteem among adolescents, failed to reach its goals. Post-campaign data showed students who enrolled in the campaign's DARE (Drug Abuse Resistance Education) program were no less likely to use drugs than those who were not exposed to the campaign. Survey results also revealed sixth graders (11-12 years of age) who enrolled in the program had lower levels of selfesteem 10 years later (Reaves, 2001). Program directors learned after the campaign's launch that kids did not respond well to the hyperbole-based rhetoric incorporated in the campaign's messages. Millions of dollars may have been saved, and much embarrassment may have been avoided if campaign coordinators had facilitated dialogue with target audiences to examine how they make meaning of health messages in the preplanning stage, which goes to show how imperative it is to conduct audience-centered research to achieve an effective campaign.

Despite its importance, there is a gap in public relations literature about how 'message-consuming publics process, seek, and evaluate' health information (Avery, 2010: 380). Avery conducted a search in Public Relations Review, Public Relations Journal and the Journal of Public Relations Research over the past 12 years and found only 12 articles on public health communication. Of those 12, only four articles (Aldoory, 2001; Anderson, 2000; Springston and Champion, 2004; Walters et al., 1997) focused on audience-centered research. With this in mind, we suggest more research that focuses on organizations' publics to provide in-depth understanding of how the intersectionality of identities affects the meaning-making process of publics which will, in turn, improve outcomes of health campaigns.

\section{Identity and intersectionality}

Identity is dynamic, fluid, multidimensional and consists of personal, communal and external frames of reference (Jenkins, 1994). The personal identity (or internal identity) deals with our thoughts, feelings and self-concept. Communal identity focuses on the tightly knit networks to which we belong based on collective histories, memories and communication practices. External identity is the socially constructed labels that are defined by others. This is also referred to as 'ascribed' identity (Sha, 2006).

Mainstream America places more emphasis on external identities (e.g. skin color or gender) without exploring other identities. For example, when Barack Obama became president, many news stories titled him the first 'Black' (or 'African American') president of the USA and revolved most of the news around this premise. However, President Obama's mother is of European descent, and his father is of African descent, which makes him as much White as he is Black. He is also a Harvard Law School graduate, community-organizer, and a father, but these identities were overshadowed by his skin color. Thus, many people react to the one identity that is most visible and salient in their minds and use this practice to classify individuals (overtly or covertly) into dominant and 
subordinate categories (Sanchez-Hucles and Davis, 2010). This hegemonic practice needs to be challenged with research that looks at intersectionality of multiple identities and not just ones that scholars have traditionally used, such as skin color or gender. In this way, public relations practitioners and researchers can begin to understand the intricate processes involved in how audience members consume messages.

One such method of examining intersectionality of identities is through anthropological research. Anthropology examines the complexity of human behavior, experiences and culture, as well as the variations among groups of humans (Lewis, 2010). Autoethnography is one anthropological methodology that helps unearth findings of multiple identities and provides rich data that can deepen researchers' understanding of how to better segment publics and to craft more targeted messages for health campaign audiences (L'Etang et al., 2010). Researchers suggest autoethnography is a better fit for intersectionality studies than traditional quantitative scale measurements and qualitative interviews; furthermore, autoethnographic research may help researchers and audiences understand intersectionality better 'when the researcher writes extensively about her personal experience relative to her multiple identities' (Vardeman-Winter et al., 2010: 25).

\section{Autoethnography}

Autoethnography is a genre of writing and research that displays multiple layers of consciousness, places the self within a social context and connects the personal to the cultural (Ellis and Bochner, 2000; Reed-Danahay, 1997). Scholars who support autoethnographic inquiry posit that it challenges the male-oriented epistemology dominating the social sciences (Neuman, 1994; Wall, 2006) by abandoning the 'rationality, objectivity, and truth to move social science beyond a focus on method, toward the power of social research' (Wall, 2006: 3).

Traditional research methods may limit new discoveries to unanswered questions because they reinforce positivist epistemologies (Eguchi, 2009). However, autoethnography is an emancipatory way of knowing that opens the door to sharing 'unique, subjective, and evocative stories of experience that contribute to our understanding of the social world and allow us to reflect on what could be different because of what we have learned' (Wall, 2006: 3). Autoethnographies allow for the emergence of new literature and offer knowledge that can explain specific social and cultural problems. In this way, autoethnography helps fill a gap of knowledge in the field of social sciences and humanities (Denzin and Lincoln, 1994). Autoethnography allows researchers to become the research subjects to help create new discourse for social change (Eguchi, 2009; Holman-Jones, 2008). In this study's context, it can help contribute to discourse that will promote more healthy individuals and help close the gap on health disparities in the USA.

Autoethnography include poetry, short stories and personal narrative (Zavattaro, 2011). Autoethnographies have been used to study subjects such as media framing of inner-city crime (Waymer, 2009), image-generating tactics on employees (Zavattaro, 2011) and the peer-review process for an autoethnographic manuscript (Holt, 2003). However, there is little (if any) research in the public relations field that employs autoethnographic research. 
This article fits into a subgenre known as analytic autoethnography. There are five key elements in analytic ethnography:

It is ethnographic work in which the researcher (a) is a full member in a research setting; (b) uses analytic reflexivity; (c) has a visible narrative presence in the text; (d) engages in dialogue with others beyond the self; and (e) is committed to improving theoretical understanding of broader social phenomena through analytic research. (Anderson, 2006: 378)

An autoethnography calls for researchers to start with their own personal lives; pay close attention to their emotions, thoughts, and feelings; analyze these data and develop associations between the self and the social/cultural context; and write a story based on these experiences (Ellis and Bochner, 2000; Waymer, 2009). Heeding this advice, my coauthor Katie and I first started with a trial week of journaling, compared notes, and discussed minor adjustments moving forward to ensure we were adhering to the elements of analytic autoethnography. We then journaled daily for two months (1 March-30 April) about our experiences, and analyzed the data. What became of the process is this enlightening, entertaining, yet scholarly article that helps extend the body of public relations literature.

\section{The autoethnographic journey}

\section{In the beginning}

What appeared to be an effortless, straightforward and easy academic article turned out to be a challenging, rigorous and colossal task - writing an autoethnography. At the outset, my co-author Katie and I agreed to write autoethnographies about the intersection of race, gender, education and motherhood status, and how those identities may or may not influence our perceptions of messages in the weight-loss process - which sounded feasible. Two weeks later, we were introduced to the complex, disciplined, reflexive and unplanned journey through the autoethnography process.

Katie and I are doctoral students with plenty on our plates (literally and figuratively speaking) and were trying to lose weight. I am a Black, childless, fifth-year doctoral student who studies public relations, health communication and weight-loss messages among minority populations. Katie is a White single mother in her fourth year of a doctoral program and studies feminism, motherhood and culture. We decided to compare our multiple identities relative to the weight-loss process for our autoethnographic article, and try to find out if, and how, our identities play a part in our mostly failed efforts to lose weight. We are emerging scholars who are both qualitatively trained, having conducted qualitative content analyses, textual analyses, ethnographies, and the like. However, neither of us had written an autoethnography ... until now.

When I invited Katie to join me on this project, I informed her that I had not written an autoethnography but would guide us through the process. Although she had not written an autoethnography either, she courageously accepted the challenge. We were both excited about contributing new knowledge and trying a new methodology, and hypothesized that writing narratives for two months would be a smooth, seamless journey, especially with our knowledge and training in an array of other qualitative methodologies. 


\section{Preparation phase}

I took several steps to help guide us through the process. First, I started out reading a few autoethnographic articles to get a sense of method, strategy, content and style when writing academic narratives. Next, I took our research focus (how race, gender, education and motherhood status may influence our perceptions of messages in the weight-loss process) and comments from the guest editors (focus more on the autoethnographic process/data) and came up with a copious list of points to cover during the journaling process. Here is a portion of it:

a. Write about the autoethnography process itself. How do you feel about journaling your experiences daily? What processes did you go through while completing the autoethnography? How do you think your experiences explain culture/social phenomena?

b. Write about messages that encourage us to, or discourage us from, the weightloss process. The messages/communication cues may be in the form of a commercial, an encouraging (or discouraging) word from family or friends, the color of weight-loss website, a logo, how a message is framed, a visual of us or someone else, etc.

c. Write about item ' $b$ ' from the lens of a white, college, female, single mother. Reflect (pause for a moment) on how your view and characteristics influence your autoethnography process.

You can imagine the look on Katie's face when I presented this daunting list to her in a meeting; I liken it to a deer in headlights. I tried my best to minimize the list, but it was a challenge because this was a new venture for me, and I did not yet have a solid grasp of autoethnographic-style writing.

The preparation process also consisted of multiple meetings between Katie and me to discuss updates, new findings, questions, thoughts, feelings, etc. relative to the process. I also reviewed our narratives to ensure we were covering points found on my laundry list of information. Furthermore, I pored over several other autoethnographic articles throughout the journey to deepen my understanding and ensure we were emphasizing the storytelling and social/cultural connections in this article. I also wanted to avoid the pitfalls mentioned in other autoethnographic manuscripts. For example, Sparkes (1996) mentioned his first drafts were heavily theorized, but after feedback from scholars and peers, decided to weave theoretical content into his narrative on an as-needed basis. In the article 'Representation, legitimation, and autoethnography: An autoethnographic writing story', Holt (2003) shared constructive criticism from journal reviewers during the peer review process for one of his autoethnographic manuscripts. One reviewer said Holt's narrative lacked 'depth' and suggested the inclusion of direct quotes from his diary. Furthermore, in Sparkes's article, a journal reviewer said he needed to conclude his article with a resolution or the lessons learned from his story. As I noted these valuable contributions to the autoethnograpic process, I shared them with Katie during each meeting. She also shared with me other articles she read about the process, and we merged our information together to help shape our journaling experience. 


\section{Article-writing phase}

With such a variation of styles when writing reflexive papers and articles, I vacillated on which one to choose. I finally settled on a thematic style. Other pieces to the puzzle I had to grapple with are how to begin this article, what literature to include, how many themes we should discuss, and what to include in the epilogue. When deciding how to bring this article together, I had to de-program my brain from the traditional scholarly forms of writing in which I have been trained, and re-program to reflect intellectual inquiry in narrative prose to extend understanding about a cultural phenomenon. Thus, what appears next are the themes that emerged from Katie's and my separate narratives about autoethnography and the weight-loss process. We included various sources of data, such as media messages, direct quotes and conversations with others, to provide depth to our narratives and to connect ourselves with the larger social and cultural context of the subject. We have also grounded our narratives in literature where appropriate, but we mostly focus on the stories we humbly share with our audience. We side with Wall in our reasoning for introducing these narratives to academia. She states: As a woman in a man's world ... and a qualitative researcher coming from a positivist discipline ... I find that the relentless nudging of autoethnography against the world of traditional science holds wonderful, symbolic, emancipatory promise' (2006: 3).

\section{Christal's journey}

I faced a barrage of obstacles in the beginning of the semester, which pretty much set the stage for the next few months of my life. Let me paint the picture for you. I was working three jobs, two of which were writing-intensive classes at a university; I was applying to, and interviewing for, out-of-state faculty positions; and I was working on my dissertation proposal. I also had a twisted ankle. During the two-month process, I was hoping to find epiphanies, moments of clarity and possibly solutions to help me in my attempt to lose weight relative to my identity as a Black graduate student with no children. Conversely, I found three overarching themes that mainly pointed to reasons why I was not winning the battle of the bulge. The three themes are: lack of time; endless reflection; and lack of consistency.

\section{Time is not on my side}

'Time is an illusion. Lunchtime doubly so.' - Douglas Noel Adams

Who has time to eat properly with such a compacted, unpredictable schedule? There were times when I had to eat on the run but attempted to make the 'healthiest' choice possible, if that is even an option for fast food places. My journal entry shows my attempt:

$3 / 3 / 11$

I was in a hurry and had no time to run home for lunch. When I was out-and-about, there was a Taco Bell and a Carl's Jr. [restaurant] nearby, but I tried to make a conscious decision to find a 
more healthy option. So, I had a ham, bacon and cheese croissant with fruit and bottled water from Jason's Deli.

Oh, did I also mention the e-mails from potential employers requesting an interview as soon as possible (i.e. within 48 hours)? On Sunday 4 April, I was leaving for church but quickly checked my e-mail account before dashing out the door. I received the following e-mail: 'Dear Crystal, we would like to conduct a phone interview tomorrow. Are you available around 12:30 or 1 pm eastern time tomorrow or Tuesday? Let me know.' Not only did the person misspell my name but also wanted an interview rather quickly. Seeing that I had no job offers, I ignored the misspelling and humbly accepted the offer. Tuesdays and Thursdays are my extremely long days, so I selected Monday for the interview. So now, I am sitting in church, stressed, trying to figure out how I am going to rearrange my schedule for the day to research and prepare for a faculty position interview.

Yes, of course, who could forget to write her autoethnography in the midst of everything else going on? Me, at times. I started out so well, but slacked off shortly - just like my plan to live a healthy life. I started the journaling process with a pen and pad in my car and purse, so when a thought hit me I would jot it down and later transcribe it. That did not last long. I was already feeling the effects of the time-intensiveness of an autoethnography as shown in this journal entry written 1 March, the first day of the journaling process:

\section{$3 / 1 / 11$}

I'm just thinking about how much effort I will have to put into an autoethnography. I have to sit down and not only record my thoughts but do it in a timely manner, be reflexive, and connect these reflections to a broader social context.

I had to constantly remind myself via post it notes and in my planner to write daily in my journal. My second-day journal entry also shows how I strived to engrain the journaling process in my memory:

\section{$3 / 2 / 11$}

I have to continuously remind myself to jot down notes for this ethnography and incorporate it into my daily schedule. I have even started carrying a notepad/pen with me so I can record thoughts, feelings, etc. on the spot and not try to save for later and then record. I'm afraid I'll forget something that might be interesting or shed light on the autoethnography if I wait. I feel like a reporter with this pad and pen. I hope I remember to do this daily!

All was well until mid-April when my overloaded cranium purged my journaling duties from my memory. When I realized that I went a day or two without writing entries in my journal, it became increasingly difficult to recall the details of my day, since everything was a blur anyway. My journal entries exemplify my failed attempts to stay abreast of my duties:

$4 / 20 / 11$

I skipped two days of my autoethnography and forgot to journal, but I'm back on it now.

$4 / 21 / 11$ 
Exercised today, but I ate fruit snacks, a few oatmeal crème pies, and a white chocolate cookie. I also ate chicken, carrots, grapefruit, I think a grilled chicken salad, and I think I had some almonds. This is what happens when you write an autoethnography retroactively; you tend to forget all of the details.

As you can tell, time was the biggest barrier in my failed attempts to lose weight. I stayed so busy that I rarely encountered mediated messages about weight-loss, because I rarely had time to see the media outside of the selected newspapers and news stations I sought out to stay abreast of current events. During the commercial segment of the newscasts, I tuned out to either accomplish another task or think about my next appointment or meeting. When I did notice commercials for weight-loss (e.g. low-fat food, diet pills, weightloss programs, etc.), I would analyze the framing of the message and how the advertisers would fail to include the risks involved, hidden costs and other variables that would probably deter a Black graduate student with a practically non-existent budget from using their products. For example, in Tsai et al.'s (2009) examination of the different weight-loss practices of obese White and minority individuals, they found that Blacks were 'significantly less likely' to use commercial programs such as Jenny Craig and Weight Watchers, which may be influenced by the programs' costs, communication of rapid weight loss, or lack of proper monitoring of participants.

Needless to say, time was not on my side. However, I believed that my consistent reflection might have helped me achieve my weight-loss goals. Reflection, therefore, was the second theme that emerged from my journal and will be discussed in the next section.

\section{Consistent reflection}

I habitually think and reflect on any and everything in my life - almost to a fault. I cruise down the street thinking, I eat my food thinking, I am reflecting even as I compose this article. To give you a snapshot of the frequency of my thought processes, I present to you evidence from my journal entries. On 1 March I wrote, 'I woke up thinking about the many Girl Scout cookies I scarfed down the night before and thinking that I need to do better and not eat so many sweets.' While I was preparing for class I was reflecting:

\section{$3 / 1 / 11$}

While getting dressed, I was thinking about what I would have for lunch and if I need to bring food from home so I could plan in advance to try and eat healthy instead of going to a fast-food joint during lunch times since Tues/Thurs are my busiest days.

I would multi-task while thinking:

\section{$3 / 7 / 11$}

While grading papers, I was thinking I need to do some type of exercises, but with my schedule, I had the option of finish grading papers or do cardio; I chose grading papers.

But I do need to exercise. And I need to remember to work on this autoethnography on a daily basis. 
What was I doing after an autoethnographic meeting with Katie? I will give you a hint:

\section{$3 / 11 / 11$}

The more I think about what we discovered at our meeting, the more I think this would be a potentially great way for people who are losing weight, or facing other health challenges, to journal about it and then reflect on their journal entries, to really understand their problem and maybe help them realize they need to get help/lose weight.

I will not belabor you with journal entries, as I 'think' you catch my drift. In case you did not though, here is one last indicator that thinking and reflecting dominates my life: The word 'thinking' appeared 24 times in my journal. Reflection was a way for me to gain some sense of control over my unpredictable schedule by cognitively mapping out strategies to eat healthier and exercise. However, when I felt defeated in my attempts, I would revert back to my old habits of not exercising and eating unhealthy food.

I should, however, celebrate the small victories. There were a few times that my reflection translated into action and healthy choices; unfortunately, those actions were short-lived and this will be covered in the next emerging theme.

\section{Three-step dance}

Do it with me now: one step forward and two steps back; one step forward and two steps back. Each time I took a step in the right direction I ended up reversing my actions through a slew of unhealthy options and a lack of exercise. At times, I was so disappointed in my lack of weight-loss that I did not bother attempting to lose weight the next few days. However, I snapped out of the funk and hopped back on the healthy horse - for a little while at least. Here are excerpts from my journal entries that exemplify my see-saw actions:

\section{$3 / 9 / 11$}

I was going to drive to IHOP [restaurant] after Bible Study to grade papers, but instead, decided to go home and eat what is there (i.e. fish, veggies) to cut down on the fat and sodium I would have consumed at IHOP.

\section{$3 / 16 / 11$}

Woke up, ate oatmeal and exercised ... yay!!! Stopped at KFC [restaurant] out of convenience and purchased three fried chicken strips. My goal is to not eat anything unhealthy and stay focused. Ate chicken and spinach for a mid-day snack, and I had an orange, banana and walnuts for a late-night snack.

\section{$3 / 24 / 11$}

I started out well again, eating an orange and oatmeal for breakfast. I had a 6-inch Subway sandwich with light ranch for lunch. But then it all came to a crash when a former student of mine came by and dropped off Girl Scout cookies that I purchased to support her daughter. Well, I ate about 15 cookies :-( 
I exercised today, and didn't eat any sweets. Go Christal!! I ate eggs, chicken, spinach, carrots, grapes, and grapefruit.

Not only I, but also my family members, contributed to my three-step dance. Researchers have found that family support plays a critical role for Black women when it comes to weight-loss efforts. Participants cited family members who 'sabotage diets' as a barrier to weight loss in Thomas et al.'s (2008) study about Black and White women's perceptions of obesity. So it was in my case when I visited my family during Easter weekend. It was Saturday 23 April, and my youngest sister Estelle inquired about ordering a pizza. Although I had thought about it earlier that day, I surely was not going to act on my own volition because I exercised that morning and wanted to make it a 'healthy' day. However, my sister truly sabotaged my efforts:

Estelle: Hey, you wanna order a pizza tonight?

Christal: Well, I'm really trying to watch my calories.

Estelle: You sure you don't want to order a pizza?

Christal: Um, well, I shouldn't.

Estelle: So, do you want to order a pizza?

Christal: OK, OK, let's order one.

Later on, Estelle tells me that she ordered extra cheese on the pizza and not to worry about the price because she is footing the bill. What broke college student passes up free pizza with extra cheese? Not this one.

Despite the pendulum success in my weight-loss attempts, I must admit that journaling my efforts was revelatory for me as illustrated in this journal entry:

\section{$3 / 11 / 11$}

Although it's [an autoethnography] time consuming, it's also revelatory because it makes me discover things. Through my ethnography, I've discovered that I've made excuses for not exercising, and excuses may be the reason I don't exercise, not lack of time. I discovered when I do have a free minute, I would rather sleep, or lounge in bed and watch television.

Reading my journal entries really made it salient that at times I substituted excuses for valid reasons to not exercise or eat a healthy diet. There were moments when the revelations fueled my desire to improve my efforts - although short-lived at times, but it helped nonetheless.

Another contributor to the three-step dance was an image of me, as written in this journal entry:

$4 / 7 / 11$

When I was changing into my night clothes, I happened to notice the circumference of my tummy. WOW! I don't ever remember it being that big!!

Albeit another short-lived effort, the image of my butterball stomach propelled me into exercise mode. There are a plethora of weight-loss commercials that show before and 
after photos of ordinary people losing weight. That may work for some, but not for me. Apparently, the image of my own body mass is what inspires me to lose weight - or at least start the process.

At times I felt guilty for not having enough willpower to exercise or eat right. Knowing my sister participated in my failed weight-loss attempts assuaged the feelings of guilt I harbored for failing to lose weight. However, I know it is ultimately my decision whether or not I make it happen and turn the three-step dance into forward-moving steps only.

Overall, I rarely encountered mediated messages with my schedule being so hectic. Furthermore, my identity as a doctoral student played an essential role in my weight-loss efforts. My identity as a Black female played a small role in my weight loss efforts with the lack of familial support, but my status as a childless woman appeared to have no bearing on my ability (or inability) to lose weight. Katie, on the other hand, has a daughter to consider when making decisions and has different hurdles to overcome. She discusses this in her narrative.

\section{Katie's journey}

The two months worth of journal entries I wrote for this project reveal many of the obstacles I have faced in my sporadic and usually short-lived attempts at weight loss. But more than that, they also reflect the stressful, chaotic, and guilt-ridden nature of single parenthood and graduate studentdom, either one of which in and of itself is typically enough to incite madness.

Through multiple close readings of my notes, three dominant themes emerged in my exploration of the weight loss process as it relates to motherhood status, education level, race and gender. However, only two of these identities present themselves as salient factors in my experiences with weight loss and weight-loss related rhetoric. First, much of my writing focused on the fact that I barely had the time or energy to write at all. An unfortunate byproduct of being a single parent and/or a full-time doctoral student is very little time to oneself, and I am no exception. The second theme was one of financial hardship. A lack of financial resources makes buying nutritious meals a challenge, and also limits my ability to participate in weight-loss programs such as Weight Watchers and Jenny Craig. Finally, I observed that most of my thoughts about weight loss were not triggered by media messages such as advertising or public relations campaigns, but instead stemmed from my interactions with, and observations about, other real-life women.

When my colleague Christal first approached me about joining her on this project, I agreed because I thought the time commitment would be minimal. There would be no interview transcription, no spending hours collecting data, and best of all, no literature review to write (not for me, at least). After all, I was to be the subject of my portion of the research and if anyone knows me, it is me. 'How hard could it be to jot down my observations about weight loss messages', I thought to myself. 'This will be a piece of cake.' Pun intended. I could not have been more wrong.

\section{Time is of the essence}

First of all, I do not tend to notice most weight loss messages, but more on that later. And, second, finding the time to write for this project was a challenge. Between preparing for, 
teaching and grading the work generated from three undergraduate classes, attending numerous weekly meetings, taking three graduate-level courses, maintaining my household and caring for my daughter and pets, I have little time for extra responsibilities. I found myself doing a lot of retroactive writing, filling in journal entries for previous days a couple of times a week. Many of my entries contain rants about how busy/stressed/tired I am. Some days, I just had nothing to say, and other days I had a lot to say, but it was not necessarily directly related to the focus of the project. On the days I did have time to write, most of my entries were about incidents that had triggered me to think about food, my body, my weight, or my self-esteem.

I found myself writing about how I often do not have the chance to eat because of my work, school, and childcare schedules, like in this entry:

\section{$3 / 21 / 11$}

I hate Mondays ... I work at OCCC [Oklahoma City Community College] from 11-2:30, then immediately have to rush to OU [University of Oklahoma] to meet with one of my professors at 3:30. I usually don't get to eat anything until after 4:30 or 5 when I pick Lola up and get home ...

And again a few days later:

\section{$3 / 24 / 11$}

Wednesdays and Thursdays are two of my long days. They are all long, but these two are particularly so. I rarely get to eat before 5 or 6 unless I grab something on my way to class ...

This same pattern emerges in many of my entries.

The same difficulties I encountered finding time to write also apply to my weight loss efforts. If I am too overscheduled and sleep-deprived to write a few paragraphs a day about weight loss messages, I certainly do not have time to implement any type of diet and exercise plan, something I wrote about in this entry:

\section{$3 / 11 / 11$}

Through this process, it has come to my attention that I feel like all the elements are conspiring against me to keep me from losing weight. With my crazy schedule, lack of time, lack of energy and lack of money, how on earth am I supposed to lose weight? I can't afford the programs; I don't have time for the gym. I don't have the energy or motivation for an at-home work out regimen.

In a trial autoethnography Christal and I conducted prior to the official start of this study, I wrote about a conversation I had with my boyfriend where he accused me of having a 'self-defeating attitude' about weight loss:

\section{$12 / 22 / 11$}

I was talking to my boyfriend before bed last night and telling him about my sister and aunt and that I was thinking of joining Weight Watchers and he asked why I didn't just use my gym membership. I told him it was just so time consuming to go to the gym - there's the time you 
spend getting ready to go, driving, actually working out, then going home, showering and getting ready to get on with the day. It's a 3-hour ordeal once all is said and done and I just don't have 3 free consecutive hours on most days. He said it's a matter of priorities and that if it's important enough to me, I will find time for it. That just pissed me off. While on one level, he's right, it just was NOT what I wanted to hear. I told him that he should take a look at my typical week and tell me just when I have that kind of time when Lola's in school and I'm not in class, teaching, or driving from one job to the other.

I realize as I am writing this portion of the article that I probably sound a bit whiney. A friend once told me 'no one cares how busy or tired you are, or what happened at the airport'. This is mostly true, and I try not to make a habit out of bemoaning my responsibilities as a student and parent because many women have not been afforded the same opportunities as I have. But given that the purpose of this project is to examine perceptions of weight loss messages and explore the conditions either promoting or encumbering attempts to lose weight, I think the discussion of time as a significant factor is relevant.

I have hinted at another consequence of my frenzied schedule that also precludes me from weight loss. Most days, I am running back and forth between classes and meetings at two universities 20 miles apart. I do not have the desire to pack a lunch to take with me, so I either do not get to eat until after 5 p.m. or I resort to driving though whatever fast food restaurant tickles my fancy that day. While most fast food joints offer salads, soups and other more healthy choices, I am often relegated to eating while driving, so those are not practical options. I typically end up scarfing down a burger or some other equally fat-filled fodder before running to my class or a meeting. My reliance on fast food is certainly not healthy, nor is it inexpensive, which leads to the second prevalent theme, money.

\section{Putting money where my mouth is}

Whether it is grabbing a sandwich on my way to work or going out with my daughter to a sit-down restaurant, it is often easier and more convenient for me to eat out. This habit, however, is expensive, and as a single parent doing two jobs to make ends meet, it is a habit I really ought to break. It does not help, though, that I hate to cook, and that cooking is not only a hassle, it ultimately just creates more work in the form of dirty dishes and a dirty kitchen. I wrote about this in one of my journal entries:

\section{$3 / 9 / 11$}

When I was going to the gym all the time back in Nov., my trainer told me never to let myself get hungry because if I did, it meant that my metabolism was already slowing down and my body was storing fat. For about two weeks, I would carry a protein bar or granola bar or something around with me in case I got hungry. It was exhausting!! I was constantly thinking about food and what I could eat if I started to feel hungry and trying to plan meals and finding the time to eat and making healthy choices when I did. Who has time for that?! I am practically the poster child for fast food. No, it's not ideal, but with my schedule, planning and packing a lunch that will actually fill me up for more than 20 minutes is not an easy task. Not to mention I have to carry a lunch bag or cooler around with an icepack, or make sure I have access to a 
microwave or something, on top of my purse and backpack which already weighs $15 \mathrm{lbs}$ from all the notebooks, papers, books and other junk I have to lug to class.

Many of the women I know who are able to maintain fitness routines, join gyms, or participate in weight loss programs such as Weight Watchers have far more disposable income than I do. In my journal, I wrote about two female relatives who have both lost a substantial amount of weight on Weight Watchers. I was impressed by their successes and thought perhaps I could do it as well. I researched the program, which costs about $\$ 40$ per month, and considered joining until I realized that not only is the program too costly for my budget, it is also time consuming to track points, count calories, weigh portions and log everything.

Not only is it too costly to join a formal program, a gym membership is out of the question as well. I had purchased one several months prior to beginning this project, and hired a personal trainer once per week for about $\$ 150$ a month. I could only absorb that cost for a few months, and had to cancel the membership and quit seeing my trainer. I realize sacrificing a few of my $\$ 20$ restaurant meals per month would probably offset this cost, but this semester, I also do not have the time to go work out, which makes it a moot point.

Another place my strained financial situation makes itself obvious is the grocery store. I am usually only able to go grocery shopping once a month, and on average I spend about $\$ 250$ each time. I primarily buy foods I know my daughter will eat. She is a picky eater, so feeding her is sometimes a challenge. Buying fresh, healthy foods is far more expensive than packing my cart with frozen dinners, cans of ravioli, boxes of macaroni and cheese, and the processed chicken nuggets my five-year-old loves so much. It is difficult to balance nutrition with cost. I can buy a package of hot dogs and a box of macaroni and cheese for less than $\$ 2$ and make at least two meals out of it for my daughter. Even when we eat out, my daughter's preferences often dictate (to an extent) what we have. In one of my journal entries, I wrote about wanting to eat at Subway restaurant, but my daughter will not eat anything on their menu, so we went to McDonald's instead.

About halfway through the data collection process for this project, I was informed my childcare expenses would be increasing substantially, from $\$ 190$ to more than $\$ 400$ a month. As a result, I had to significantly alter my spending habits. I dramatically reduced the amount I eat out, and trimmed my grocery budget as well. By the end of the month, there is not a whole lot, if anything, left in my pantry or my bank account. In addition to making weight loss more difficult by further constraining my ability to buy healthy meals, the added stress has pushed my weight loss goals to the sideline. I have far more pressing issues to worry about than losing weight.

These two themes correspond closely with the ideology of intensive mothering proposed by Hays (1996) and supported by Rubenstein (1998). According to this theory, spending money and taking time away from children and family to pursue personal goals and desires is inconsistent with good mothering practices. In order to maintain a workout regimen, I would need to hire a babysitter to care for my daughter while I went to the gym. Aside from being out of reach financially, I would also be putting my own wants before those of my daughter. By not taking care of myself in this regard, I am demonstrating my 
dedication to my child and ideology of intensive mothering. Additionally, by making food choices consistent with my daughter's tastes rather than mine, I am further adhering to this philosophy.

Ironically, however, this commitment has potentially negative consequences extending beyond the health consequences and lessons I may be teaching my daughter. Teachman et. al (2003) found evidence of an implicit fat-bias, where overweight and obese individuals were perceived (relative to thin people) as being lazy, stupid and worthless. The negative stereotypes associated with overweight people, when combined with the ideology of intensive mothering, put many mothers in a vicious double-bind. In order to combat the social stigma that they are lazy, worthless and stupid, overweight mothers would need to take time to exercise, eat right and care for themselves, which runs contrary to acceptable mothering principles outlined by the ideology of intensive mothering.

\section{Constant comparisons}

The third and final significant theme I observed in my journal entries was how little I tend to notice weight-loss rhetoric. Sure, I see the commercials, billboards, infomercials, magazine advertisements, pop-up ads online, etc., but I do not really pay them any mind. In one of my journal entries, I wrote about why this might be:

\section{$4 / 13 / 11$}

... thanks to my 9 years studying media and representation ... [I know] that media images are total fabrications. Women in real life don't look like the women on TV, and believing that they do can cause irreparable harm to one's self esteem and mine is fragile enough as it is.

In the beginning, the objective of this project was to examine the messages that encouraged or discouraged Christal and me from the weight loss process. I was supposed to think about specific communication cues that prompted me to think about weight loss in a positive or negative way. As it turns out, however, these types of messages have little impact on me because I know they are a gimmick. The photos and commercials are airbrushed or digitally enhanced, and most of the products are ineffective or unsafe. The cues that have the most impact on me tend to be my interactions with, and observations of, other real women.

Going out to a bar and seeing other women my age dressed up in cute outfits; watching men ogle the nude bodies of exotic dancers during a much contested visit to a strip club; those are the types of experiences I wrote about that prompted me to reevaluate my (lack of) weight loss efforts. On only a couple of occasions did I write about media messages, and in those cases, it was often because I found them so ridiculous, like this entry:

\section{$4 / 17 / 11$}

I saw a Jenny Craig (I think) commercial featuring Sara Rue today. I like her. She's cute. And I thought she was cute chubby too, but now she's lost a lot of weight and looks great. I wish I could believe all she did was eat pre-packaged Jenny Craig food. Ha. I guess maybe I'm too much of a skeptic for the weight loss industry to be effective. 
I often become discouraged when comparing my body to other women, however, because I know my body will never look the way I want it to. Even if I were to lose weight, my breasts would still sag, my stretch marks would still be visible, and I would still never be able to wear a two-piece swimsuit. I would require extensive (and very expensive) cosmetic surgery in order to remove the excess skin and repair the muscle damage caused by my pregnancy, a fact I have verified with two different plastic surgeons. I am 27 years old, and my body has been irreparably damaged by my lifestyle choices. I am uncomfortable in my own skin, and that is not something any weight loss pill, website, commercial, diet program or public relations campaign can change. Sure, exercise can boost selfesteem, and if I lost weight I might feel better about myself, but I will never have the body I wish for.

\section{Both journeys combined}

These two narratives give insight into the lives of two doctoral students as they discuss their daily struggles of weight loss relative to their intersectionality of identities. The narratives reveal noteworthy findings that will contribute to public relations scholarship.

Overall, both authors felt they lacked control over certain situations in their lives (e.g. time, money, food choices). This was exemplified when Christal thought she had no control over her schedule and when Katie believed that her disposable income, hectic schedule and her daughter's food preferences influenced her weight-loss decisions. According to Ross et al. (1990), when people believe they have no control over an issue, they are unmotivated to solve problems. In our case, Katie and I perceived that we lost control of our various situations, so we found it pointless to attempt to solve our weightloss problem.

From this, health communicators should learn about what specific barriers the audience face and how these constraints influence their decisions. Our ethnography reveals the need to abandon the one-size-fits-all approach to health campaigns, and instead, examine the complex identities of audience members to more effectively target health messages to key publics.

Both women identified the lack of time as a barrier to losing weight. Christal mentioned doing her various jobs while interviewing for out-of-state faculty positions, while Katie's schedule focused more on her job and taking care of her daughter. McMunn et al. (2006) said that socially valued activities such as parenthood and employment impact women's health and health decisions; thus, health messages need to account for the different social roles that influence women's behavior when it comes to weight loss.

Conversely, practitioners use predetermined strategies from the organization to segment publics, such as targeting messages based solely on similar geographic factors. Using this traditional method, Katie and I would have received the same health message based on our same gender and educational status, without accounting for our various social roles of a busy traveling doctoral student and a busy mother. This may have resulted in failed attempts to increase our involvement and decrease constraints in the campaign's messages. Therefore, it is imperative for public relations scholars to embrace methodologies (such as autoethnography) that will assist in creating messages that address the social roles that are situated within multiple intersecting identities rather than 
using reproduced knowledge created by organizations (Lupton, 1994; Vardeman-Winter and Tindall, 2010)

Another finding in our narratives is the different cues to action when it came to the weight loss process. Glanz et al. (2008) defined cues to action as something that activates 'readiness' to take action. Looking at an image of my portly shape encouraged me to put more effort into losing weight. Katie, on the other hand, was moved by observations of other women in her age bracket with cute outfits and nicely toned physiques. Research suggests that strong ethnic identity protects Black women from being affected by thin images of other women and ideal beauty standards of American culture (Perez and Joiner, 2003). This may be why I was not influenced by other women's body images. However, researchers have posited that this same protection may lead to an 'unhealthy tolerance' of obesity (Ristovski-Slijepcevic et al., 2010). Awareness of this ethnic difference would help public relations professionals decide how to strategically use messages and images to more effectively communicate with different racial and ethnic groups. The ethnic variation of our cues to action further reveals the complexities in segmenting publics for health communication campaigns and reveals the need for more methodologies such as autoethnography that will uncover the multiple identities and experiences of an organization's public.

The reflexivity of the journaling process is another finding that may benefit individuals who are attempting to lose weight. My autoethnographic experience helped me realize that I substituted excuses for exercising, which moved me to short-term action. The journaling process, therefore, may be one activity health communicators implement in weight-loss campaigns as a means of moving their publics to achieve short-term weight loss goals.

A final point worth mentioning is our experiences with autoethnography. My coauthor Katie and I believed our narrative research would consist of simply keeping a diary and would require little involvement - on the contrary. Collectively, we spent more time preparing for and writing this article than most of the other traditional research papers and articles we have written in the past. Much rigor was involved in the pre-data collection stage, the journaling process, and the data analysis and reporting stages. Much time, effort, and energy was spent to not only tell our stories but to illustrate how our individual voices are culturally situated to provide rich meaning to the social phenomena of identity and weight loss. Critics of autoethnographies have said narrative research lacks rigor and valid representation of cultural and social phenomena because they focus on a single subjective researcher (Eguchi, 2009; Wall, 2006). We would venture to say those who disregard autoethnography as a viable methodology have never written one.

In conclusion, we know our findings are not generalizable. However, our narratives fill a gap in literature by focusing on a more detailed audience-centered methodology than traditional quantitative and qualitative studies. The article also introduces a more in-depth look at the intersectionality of identities than what focus groups or one-on-one interviews can offer. We hope this encourages public relations scholars and practitioners to move beyond traditional race and gender examinations and explore other intersectionality of identities that will increase effective communication to audiences, and mutually beneficial communication between an organization and its publics. 


\section{Funding}

This research received no specific grant from any funding agency in the public, commercial, or not-for-profit sectors.

\section{References}

Aldoory L (2001) Making health communications meaningful for women: Factors that influence involvement. Journal of Public Relations Research 13(2): 163-185.

Anderson L (2006) Analytic autoethnography. Journal of Contemporary Ethnography 35(4): $373-395$.

Anderson RB (2000) Vicarious and persuasive influences on efficacy expectations and intentions to perform breast self-examination. Public Relations Review 26, 97-114.

Avery E (2010) Contextual and audience moderators of channel selection and message reception of public health information in routine and crisis situations. Journal of Public Relations Research 22(4): 378-403.

Centers for Disease Control. (2009) Overweight and obesity: Causes and consequences. Available at: www.cdc.gov/obesity/causes/index.html (accessed 8 December 2011).

Centers for Disease Control. (2012) HIV Mortality through 2008. Available at: www.cdc.gov/hiv/ topics/surveillance/resources/slides/mortality/index.htm (accessed 10 April 2012).

Denzin NK and Lincoln YS (1994) Entering the field of qualitative research. In Denzin NK \& Lincoln YS (eds) Handbook of Qualitative Research. Thousand Oaks, CA: Sage, pp.1-17.

Eguchi S (2009) A narrative about making sense of 'Asian American' identity: Cross-cultural transformation from gay 'Japanese' man to gay 'Asian American' man . In: National Communication Association Conference, Chicago, IL, November.

Ellis C and Bochner A (2000) Autoethnography, personal narrative, reflectivity: Researcher as subject. In: Denzin NK and Lincoln YS (eds) Handbook of Qualitative Research. Thousand Oaks, CA: Sage, pp.733-768.

Glanz K, Rimer B and Viswanath K (eds) (2008) Health Behavior and Health Education: Theory, Research and Practice, 4th edition. San Francisco: Jossey-Bass.

Hays S (1998) The Cultural Contradictions of Motherhood. New Haven, CT: Yale University Press.

Holman-Jones S (2008) Autoethnography: Making the personal political. In: Denzin NK and Lincoln YS (eds) Collecting Interpretive Qualitative Materials. Thousand Oaks, CA: Sage, pp.205-246.

Holt NL (2003) Representation, legitimation, and autoethnography: An autoethnographic writing story. International Journal of Qualitative Methods 2(1): 18-28.

iCrossing. (2008) How America searches: Health \& wellness. Available at: www.icrossing. com/icrossing-study-finds-the-internet-is-top-resource-for-health-information (accessed 20 February 2012).

Jenkins R (1994) Rethinking ethnicity: Identity, categorization, and power. Ethnic and Racial Studies 17(2): 197-223.

L'Etang J, Hodges C and Pieczka M (2010) Call for papers: Public relations anthropology and ethnography. Public Relations Review 36(2): 1.

Lewis TA (2010) Ethnography, anthropology, and comparative religious ethics: Or ethnography and the comparative religious ethics local. Journal of Religious Ethics 38(3): 395-403.

Lupton D (1994) Toward the development of critical health communication praxis. Health Communication 6: 55-67.

McMunn A, Bartley M and Kuh D (2006) Women's health in mid-life: Life course social roles and agency as quality. Social Science and Medicine 63(6): 1561-1572. 
Neuman WL (1994) Social Research Methods: Qualitative and Quantitative Approaches. Needham Heights, MA: Allyn and Bacon.

Perez M and Joiner TR (2003) Body image dissatisfaction and disordered eating in Black and White women. International Journal of Eating Disorders 33(3): 342-350.

Pew Research Center. (2010) Key news audiences now blend online and traditional sources. March. Available at: www.pewinternet.org/ /media//Files/Reports/2010/PIP_Understanding the Participatory_News_Consumer.pdf(accessed 11 September 2012).

Pratt CB (2007) Crafting campaign themes (and slogans) for preventing overweight and obesity. Public Relations Quarterly 52(2): 2-8.

Reaves J (2001) Just say no to DARE. Time Magazine, February. Available at: www.time.com/ time/nation/article/0,8599,99564,00.html\#ixzz1e5cFPPMv (accessed 24 March 2012).

Reed-Danahay D (1997) Auto/Ethnography. New York: Berg.

Ristovski-Slijepcevic S, Bell K, Chapman G and Beagan B (2010) Being 'thick' indicates you are eating, you are healthy and you have an attractive body shape: Perspectives on fatness and food choice amongst Black and White men and women in Canada. Health Sociology Review 19(3): 317-329.

Ross C, Mirowsky J and Goldsteen K (1990) The impact of the family on health: The decade in review. Journal of Marriage and The Family 52(4): 1059-1078.

Rubenstein C (1998) The Sacrificial Mother. New York: Hyperion Books.

Sanchez-Hucles JV and Davis DD (2010) Women and women of color in leadership: Complexity, identity, and intersectionality. American Psychologist 65(3): 171-181.

Sha, B-L (2006) Cultural identity in the segmentation of publics: An emerging theory of intercultural public relations. Journal of Public Relations Research 18: 45-65.

Sparkes AC (1996) The fatal flaw: A narrative of the fragile body-self. Qualitative Inquiry 2(4): 463-494.

Springston JK and Champion VL (2004) Public relations and cultural aesthetics: Designing health brochures. Public Relations Review 30(4): 483-491.

Teachman BA, Gapinski KD, Brownell KD, Rawlins M and Jeyaram S (2003) Demonstrations of implicit anti-fat bias: The impact of providing causal information and evoking empathy. Health Psychology 22(1): 68-78.

Thomas A, Moseley G, Stallings R, Nichols-English G and Wagner P (2008) Perceptions of obesity: Black and White Differences. Journal of Cultural Diversity 15(4): 174-180.

Tsai AG, Wadden TA, Pilliterri JL, Sembower MA, Gerlach KK, Kyle TK, \& Burroughs VJ (2009) Disparities by ethnicity and socioeconomic status in the use of weight loss treatments. Journal of the National Medical Association, 101(1): 62-70.

Vardeman-Winter J and Tindall NTJ (2010) 'If it's a woman's issue, I pay attention to it': Gendered and intersectional complications in The Heart Truth media campaign. Prism 7(4). Available at: www.prismjournal.org (accessed 12 March 2012).

Vardeman-Winter J, Tindall NTJ and Jiang H (2010) The possibilities and realities of studying intersectionality in public relations. In: Association for Education in Journalism and Mass Communication, Denver, CO, August.

Wall S.(2006) An autoethnography on learning about autoethnography. International Journal of Qualitative Methods 5(2): 1-12.

Walters TN, Walters LM, Kern-Foxworth M and Priest SH (1997) The picture of health? Message standardization and recall of televised AIDS public service announcements. Public Relations Review 23: 143-159.

Wang X and Arpan LM (2008) Effects of race and ethnic identity on audience evaluation of HIV public service announcements. Howard Journal of Communications 19(1): 44-63.

Waymer D (2009) Walking in fear: An autoethnographic account of media framing of inner-city crime. Journal of Communication Inquiry 33(2): 169-184. 
Wise K (2001) Opportunities for public relations research in public health. Public Relations Review 27(4): 475-487.

World Health Organization. (2011) Obesity and overweight fact sheet. Available at: www.who.int/ mediacentre/factsheets/fs311/en/index.html (accessed ?).

Zavattaro SM (2011) An autoethnographic tale of image-generation tactics on employees. Employee Responsibilities and Rights Journal 23(1): 1-16.

\section{Author biographies}

Christal R. S. Johnson is an Assistant Professor of Advertising at Howard University in Washington DC. She earned her bachelor's degree in journalism (advertising) from the University of MissouriColumbia and her master's degree in journalism (public relations) from the University of North Texas. She will be completing her doctoral degree from the University of Oklahoma in December 2012. Her research interests include strategic communication, obesity and weight loss messages, and minority audiences. Christal is a member of the advertising division of the Association for Education in Journalism and Mass Communication (AEJMC), Public Relations Student Society of America (PRSSA) and the National Association of Black Journalists (NABJ). She is a community service volunteer through the Greater Washington Urban League Young Professionals.

Katherine L. Eaves is a doctoral candidate in the Gaylord College of Journalism and Mass Communication at the University of Oklahoma. She earned her bachelor's degree in print journalism and master's degree in communication from Wichita State University, Kansas. Her research focuses primarily on the intersection of media, gender, representation and identity formation. She is primarily interested in critically examining the ways in which popular media depict mothers, and how those representations shape cultural norms and expectations about motherhood. Prior to pursuing her $\mathrm{PhD}$, Katherine worked as a community journalist, public relations practitioner and broadcast news producer. She is currently an Adjunct Professor of Speech Communication at Oklahoma City Community College and a Graduate Research Assistant at the University of Oklahoma. She is also a member of the Association for Education in Journalism and Mass Communication, the National Communication Association and the Organization for Research on Women in Communication. 